\title{
Beyond Belief: Chance, Authorship, and the Limits of Comprehension in Gerhard Richter's Strip
}

\author{
James Romaine \\ Art Department, Lander University, Greenwood, SC 29649, USA; jromaine@lander.edu
}

Received: 2 February 2019; Accepted: 12 April 2019; Published: 17 April 2019

\begin{abstract}
For nearly six decades, Gerhard Richter has challenged the conceptual and visual limits of contemporary painting. His 2011 work Strip overloads the viewer's visual perception. Richter created this unique digital print using a process that deliberately employs chance to circumvent the artist's authorship. This article examines the history of Richter's skepticism of creative authority and the strategies he has developed to realize an art that exceeds the limits of human skill and imagination. Although he remains an atheist, Richter frames his pursuit of an incomprehensible art in terms of a longing for a belief in God.
\end{abstract}

Keywords: Gerhard Richter; contemporary painting; Strip; chance; belief; skepticism; authorship; abstract painting; Cologne Cathedral window

Strip (921-6) is a unique digital print by Gerhard Richter. ${ }^{1}$ This sensational 2011 work, in the permanent collection of the Tate Modern, London, is arguably one of the most conceptually fresh and art historically important works by the contemporary German artist. In both its visual presence and the process of its creation, Strip evidences an organic life that exceeds the limits of the artist's authorship and the viewer's perception. It is a model of a reality in which creativity and chance realize an other-worldly beauty that is the materialization of what Richter called, "the highest form of hope." 2

According to Richter, our capacity to believe in the existence of something greater than ourselves, something that is incomprehensible to the human mind, is our greatest human characteristic. He further asserts that art is the only means of realizing that belief in material and present form. In notes to himself, dated 3 January 1988 and published in his collected writings, interviews, and letters, Richter wrote, "Art is a pure realization of religious feeling, capacity for faith, longing for God." But then he continues, following this confident pronouncement with a caution,

All other realizations of these [religious feeling, capacity for faith, longing for God], the outstanding human qualities, abuse these qualities by exploiting them: that is by serving an ideology. Even art becomes 'applied art' just as soon as it gives up freedom from function and set out to convey a message. Art is human only in the absolute refusal to make a statement.

However, Righter concludes this written thought to himself on a more optimistic note, "The ability to believe is our outstanding quality, and only art adequately translates it into reality. But when we assuage our need for faith with ideology, we court disaster." 3

1 Between 2010 and 2015, Richter created eighty-six digital prints, all of these are entitled Strip. The designation (921-6) is from Richter's self-created Catalogue Raisonné and serves to distinguish this work from the rest of the series. This Catalogue Raisonné is part of the artist's website, gerhard-richter.com. Hereafter, the title Strip will only be used in reference to Strip (921-6).

2 “Text for catalog of documenta 7, Kassel, 1982" in (Richter et al. 2009, p. 121).

3 "Notes, 1988" in (Richter et al. 2009, p. 200). 
Richter has had, from the very beginning of his career, a belief in painting and a suspicion of artistic authorship. This contradiction has motivated him to push the conceptual and technical limits of painting for nearly six decades. From his paintings based on banal media and family photos to his mastery of a technique of smearing abstract skins of paint with a squeegee tool that he developed himself, Richter has been one of the most conceptually astute and technically facile painters of the past half century. While much of the abstract painting produced in this period has been either, on the one hand, heir to the modernist conception of the work of art as the expression of the artist's inner feeling or, on the other hand, cynical end-game musings on the theoretical "death of painting," Richter's methodical pursuit of a third path consistently has been conceptually innovative and visually spellbinding. ${ }^{4}$

Richter has been richly rewarded for his efforts. He is one of the most commercially successful and critically acclaimed living artists. ${ }^{5} \mathrm{He}$ is regularly counted, by art critics and curators, among the most important living painters. The voluminous literature on his art, from scholarly articles, to exhibition catalogs, to monographs, evidences how Richter is one of the widely celebrated and sharply contested contemporary artists.

Every work of art proposes a way of looking at the world. It makes this proposition not only in what it depicts but also in how it depicts. Strip challenges the viewer's senses; it overloads the viewer's visual perception. If the senses are how the viewer apprehends the world, Richter presents the viewer with the limitations and potential impairments of these tools. This essay examines Strip as a fulfillment of Richter's pursuit of an art that is, paradoxically, a realization of our capacity to believe without falling into what he regards as the fallacy of personal expression. Rather than speaking to the viewer about politics or religion, Richter's art confronts the self-aware viewer with both the limitations of their own present-state being and the prospect of a reality that is beyond our comprehension. ${ }^{6}$

\section{Encountering the Incomprehensible}

Measuring $200 \times 440 \mathrm{~cm}$, Strip is composed of countless thin horizontal bands of different colors. These lines are perfectly straight, parallel, and run from one edge of the work to the other. Their optical velocity is unconstrained by any frame within or around Strip. ${ }^{7}$

Strip is majestic and hallucinatory. Its lateral rush of color has no discernable composition or focal point. The pulsating strokes of nonmimetic color do not repeat in any vertical pattern. And yet, Richter's work is visually balanced and harmonious. This work is slightly more than twice as long as it is high. This gives the work a visual impression of material growth. Unified by a limited range of color (both hue and value), Strip has an indefinable, but certainly recognizable, organic beauty.

Strip exceeds the possibilities of traditional painting or drawing. Reproducing this digital print by hand, to draw countless perfectly straight lines that measured $440 \mathrm{~cm}$ in length, would be nearly impossible. As such, the work immediately announces itself as a digital creation.

While these perfectly straight and parallel threads of color seem to run from one edge of the work to the other without interruption, Strip, in fact, has a midpoint divide. This seam is not perceptible in reproduction but Richter's online Catalogue Raisonné identifies that this work has "2 parts."

4 Painters, working in abstraction, whose work might be considered, at least by them, an expression of their inner expression include Ross Bleckner, Yayoi Kusama, the artist collective Tim Rollins and K.O.S., and Julian Schnabel. Painters whose work could be described as embracing the so-called "death of painting," include Daniel Buren, Peter Halley, and Allan McCollum.

5 Richter's achievements in the art market, the countless exhibitions of his art around the world, and the voluminous literature on his work are all meticulously documented on his website, gerhard-richter.com.

6 After employing a careful examination of Strip, and its process of creation, to frame the question of creative authorship in Richter's art, this essay traces the personal and artistic maturation that brought Richter to the Strip Paintings. The essay concludes with an examination of the issue of chance and authorship that Richter's oeuvre raises as well as his proposition that painting can address, if not fully satisfy, the fundamental human longing for God.

7 Some other prints from the Strip Painting series do have borders. 
This vertical seam in Strip is not actually necessary to the work. There are prints from the Strip Painting series, measuring more than twice as long as the work at the Tate Modern, that are one single piece. ${ }^{8}$ However, this vertical break in the horizontal midpoint is intentional and conceptually essential to the work. Strip is a unique work; as such it participates in a conversation about "aura" in contemporary art. But, at the same time, Strip is composed of two identical parts. ${ }^{9}$ These twin halves of Strip are each $200 \times 220 \mathrm{~cm}$. They are nearly square, which gives them a visual solidity. Each partner maintains its individuality within the totality of the work. However, since the right half is a perfect reproduction of the left and the left is a perfect reproduction of the right, Strip exemplifies the aura and its double.

Strip has a powerful visual presence. As part of Gerhard Richter's continuous investigation of painting within the photographic and digital age, Strip is one of the most visually engaging and conceptually clever works within an already impressive oeuvre.

There is no way to completely see Strip. It is taller than many viewers and, since it doesn't rest on the floor, about half of these bands of color are higher than the average viewer. If one stands back from the work, far enough for the work to remain within the viewer's field of vision, the lines are too small to be visually differentiated. They begin to optically blur, but this creates new lines. In fact, as one approaches Strip, starting from across the gallery, the discernable bands of color seem to spontaneously multiply with each step. One line becomes two, four, eight new lines. One color becomes two, four, eight new colors. The closer that we get to the work, the more colors and lines magically appear. There is a sense that if we could somehow get even closer, that there could be more bands within bands of color than we haven't yet perceived.

Could one actually count the lines in Strip? Possibly. But they exceed what the eye and mind of the viewer standing in the gallery can comprehend. Without actually being infinite, these striations evoke infinity. There is a palpable impression that there is an unfathomable world within Strip that we might be able to step into.

Strip's expansive length and its nearly hallucinogenic vibration of color creates a perception, particularly if one is standing near the center and close to the work, that it extends endlessly. Even when we are visually able to find the edges, Strip evokes a reality that has no beginning or end or edges. Through Strip, we transgress into the realm of the unknowable.

While Strip provides the viewer with visual enchantment, it also poses a challenge to anyone tasked with finding words to describe this experience. As Richter himself noted, "To talk about painting is not only difficult but perhaps pointless, too. You can only express in words what words are capable of expressing, what language can communicate. Painting has nothing to do with that." 10 And yet, Richter is one of the most verbally articulate and insightful contemporary visual artists. The published collection of his writings and interviews, from 1961 to 2007, runs more than 500 pages. As much as any living artist, the literature on Richter's art is constructed around his own characterization of his art.

One term that Richter repeatedly employs in discussing his art is "incomprehensible."11 In notes to himself, dated 1981, Richter described his aim being, "Painting is the making of an analogy for

Strip 930-1, 930-2, 930-4, and 930-6 are each $1000 \mathrm{~cm}$ long. Strip 930-7 measures $1100 \mathrm{~cm}$ in length. All of these are one piece. Within the Strip Paintings series, there are also works that are divided into three and four identical units. The vertical divides in these Strip works also make reference to one of Richter's most admired artists, the Abstract Expressionist painter Barnett Newman. Also, the division of these works into identical units, places Richter's art in the company of Minimalist and Post-minimalist painting. However, the contribution of Strip to the history of abstract painting is outside the scope of this essay.

10 Gerhard Richter in (Belz 2012).

11 The concept of "incomprehensibility" has numerous histories and interpretations within various philosophical and religious traditions. However, the question that concerns this essay is "what does 'the incomprehensible' mean to Richter and how is this, then, manifested in his methods and works of art?" Rather than diverging into tangents of what "incomprehensibility" might mean within sundry philosophical and religious traditions (which Richter may or may not have studied and which he, in all likelihood, would have rejected) this essay focusses on a close examination of Richter's extensive writings and interviews to formulate a better understanding of the artist's evolving beliefs. 
something non-visual and incomprehensible: giving it form and bringing it within reach. And that is why good paintings are incomprehensible."12 Richter returned to this idea in notes from 1985, stating that, to his achieve his aim, his process should be "painting like nature, painting as change, becoming, emerging, being-there, ... and incomprehensible." ${ }^{\prime 13}$ These are incomprehensible means to realize incomprehensible ends. And, in a 1998 interview, Richter told Mark Rosenthal, "the structure of my works is so complicated and difficult so that they are incomprehensible ... . If you want, you may call it metaphysical."14

Richter has also used "incomprehensible" to describe God. In a 2011 interview, he described the complex contradictions of his doubts and beliefs saying, "we can't exist without some form of belief in things ... . Even as an atheist, I believe. We are just built that way." He added, "I believe that you always have to believe ... But I can't believe in God, as such, he's either too big or too small for me, and always incomprehensible, unbelievable." 15 In that same interview, Richter said that a successful painting must have "something incomprehensible, something that is on a higher plane."16

These 1998 and 2011 interviews bracket the genesis of Richter's Strip Paintings series, and suggest the direction of Richter's thinking that brought him to Strip. While he aspires for his art to have metaphysical content, Richter achieves this spiritual aim through material and rational means, by extending material and logic beyond itself. If the incomprehensibility of any structure in a work of art is its measure of metaphysical effect, Strip is absolutely metaphysical.

\section{Creating Strip}

To create Strip, Richter started with a photograph of one his own paintings, Abstract Painting (724-4). ${ }^{17}$ This 1990 painting is visually rich in color and detail, making it ideal for Richter's process. He began by scanning a photograph of Abstract Painting. Starting with a detail of this scanned image, he then used a computer to systematically rework the image by first vertically dividing it and then joining each of the halves with a mirror image of itself. This created two new images, and two new starting points. Richter, using a computer, repeated this process twelve times. One picture was multiplied into two; two became four; four became eight. Richter continued this process until he had four thousand and ninety-six unique images. By this point, the image of Abstract Painting had been transformed into eight thousand one hundred and ninety striations of color that were, each, only $0.00762 \mathrm{~cm}$ wide.

Richter selected, discarded, and recombined these narrow strips. It was previously noted that each example from the Strip Painting series is unified by a limited range of color. This is evidence of Richter's creative intervention into and reorganization of the eight thousand one hundred and ninety strips created by the computer. He then used a process of mirroring to extend these strips into the horizontal bands of color that stretch across the work we encounter at the Tate Modern.

The process of creating Strip is simultaneously logical and random, methodical and intuitive. Richter documented this process of artist-directed chance in a book Gerhard Richter: Patterns: Divided, Mirrored, Repeated. ${ }^{18}$ Looking through the book, it is possible, at first, to follow the process. While it requires concentration, it is manageable to track how the detail of one page becomes multiplied on the next several pages (since at each stage the number of new images is compounded). Abstract Painting

\footnotetext{
"Notes, 1981" in (Richter et al. 2009, p. 120). Italics added.

"Notes, 1985" in (Richter et al. 2009, p. 142). Italics added.

"Interview with Mark Rosenthal, 1998" in (Richter et al. 2009, p. 330). Italics added.

"I Have Nothing to Say and I'm Saying It." in (Godfrey et al. 2016, p. 24). Italics added.

"I Have Nothing to Say and I'm Saying It." in (Godfrey et al. 2016, p. 22). Italics added.

All the prints from the Strip Painting series are derived from Abstract Painting (724-4). Like Strip (921-6), Abstract Painting (724-4) can be distinguished from Richter's other paintings, also titled Abstract Painting, by its Catalogue Raisonné number. Hereafter, the title Abstract Painting will only be used in reference to Abstract Painting (724-4). Abstract Painting is in a private collection, it sold at Christie's in 2006 for $\$ 1,338,434$.

18 (Richter 2012)
} 
becomes a set of increasingly intricate patterns. It is fun, at first, to even try to look at a page and try to imagine (by dividing, mirroring, and repeating in the mind) how the next page/pages might look.

However, as eight becomes sixteen and sixteen become thirty-two, one begins to lose track of the process. By sixty-four, the viewer is likely to become increasingly lost in the process and, by one hundred and twenty-eight, it became useless to even try to follow the evolution and multiplication of the images. Richter must have recognized this breaking point himself because, after sixty-four, the book only reproduces select examples from the last six stages of transformation. (To reproduce every image from every stage would require a book of eight thousand one hundred and ninety pages.) However, Gerhard Richter: Patterns: Divided, Mirrored, Repeated is instructive. It allows the reader to trace a process that is at first logical and finally becomes incomprehensible. It allows the reader to find the breaking point of their concentration, of the limits of their imagination.

\section{The Problem of Painting}

Strip is part of a series that Richter began in 2010. Despite the fact that these works are unique inkjet prints, this series is collectively titled Strip Paintings and Strip is listed in Richter's Catalogue Raisonné as a painting. ${ }^{19}$ By designating these digitally created abstract images as "paintings," Richter provocatively challenges the definition of "painting" in a digital age. ${ }^{20}$ But there is, potentially, something even more significant at stake in calling Strip a painting. If we consider a "painting" to be a unique and handmade work of art and a "print" to be mechanically created multiple, "painting" has an inherent authoritative voice. Richter acknowledges this when he said, "I like how Adorno explained it: you can't put pictures together. Paintings are always 'mortal enemies' ... . Every painting is an assertion that tolerates no company." ${ }^{21}$ Every painting asserts its position as an authoritative statement about how to see the world. Situating Strip, which is a mechanically created unique work, in the category of "painting" enables Richter to address what might be the central issue of his artistic project, namely the problem of an authoritative voice that painting might suppose.

Strip, and its related works from the Strip Painting series, represents one of the most significant developments in Richter's entire oeuvre. However, this essay is not primarily concerned with what the Strip Painting series might mean for painting in a digital age, which is a question mainly of interest for art theorists, or whether these unique digital works should be counted as paintings at all, which is a question mainly of concern for the art market. ${ }^{22}$ This essay explores Strip and the Strip Painting series as a culmination of Richter's artistic method and his skeptical attitude toward artistic authorship. By situating Richter's Strip within his oeuvre, we can examine it as the fulfillment of a career-long maturation process in the purpose and visual strategies of his art. Therefore, before exploring the issues of chance and authorship evidenced in Strip, we should briefly trace some of the personal and artistic evolution that brought Richter to this work.

19 The Strip Painting series are cataloged in Richter's own Catalogue Raisonné as "paintings," even though he has a section for "prints." Works from the Strip Painting series have been exhibited in several gallery shows, including Gerhard Richter: Painting 2010-2011, Galerie Marian Goodman, Paris, France, 23 September 2011-3 November 2011 and Gerhard Richter: Painting 2012, Marian Goodman Gallery, New York, USA, 12 September 2012-13 October 2012. The point is that Richter has repeatedly asserted that these unique digital prints belong, in his mind, within his painting oeuvre.

20 There are market reasons why Richter would categorize these large unique prints as "paintings." However, across his career Richter has both shown an indifference to the art market as well as a commitment to continually challenging the boundaries of "painting." Richter has said, "Today I find that art mostly has to fulfill economic conditions. That's no good either. Art had to be truthful—that's its moral aspect" (van Bruggen 1985, p. 82).

21 Gerhard Richter in (Belz 2012). Presumably, since they are by nature not unique, photographs and prints have no choice but to tolerate the company of other images.

22 For a discussion of what the Strip Painting series might mean for the current state of painting, see (Buchloh 2012). 


\section{Formative Experiences}

The paradoxes of his art, his suspicion of creative authorship and his embrace of artist-directed chance, are, in part, rooted in the complexity of Richter's early life experiences, first under Nazism and then under Soviet Communism, as well as his education at the Dresden Art Academy.

Richter was born February 9th, 1932 in Dresden, Germany. During the years of the Second World War, he lived in the village of Waltersdorf with his mother Hildegard and sister Gisela. His father, Horst, who had been a teacher, was conscripted into the military. Waltersdorf is about 60 miles north of Dresden and was spared the type of devastation that Dresden suffered under Allied bombing. Richter was enrolled in the Hitler Youth but found ways of avoiding participation. By his own account, he had little direct experience of the war and has few memories of that period. Nevertheless, this formative experience impressed upon Richter the violence to which total belief in an ideology could, perhaps inevitably, give birth.

In 1951, Richter returned to the ruins of Dresden and began to study at the Dresden Art Academy (Hochschule für Bildende Künste Dresden). Since 1949, Germany had been divided between the Western Allies and the Soviet Union. Dresden was in the German Democratic Republic (GDR), often called East Germany. At the Dresden Art Academy, Richter had a classical visual art education that emphasized drawing and representation. At the academy, Richter was taught that all forms of technique are ideological and that art found its purpose in the service of advancing the messages of the state. For example, at the academy, traditional realism was championed while modernist abstraction was suppressed, for ideological reasons. But the result of this formative training is that Richter is fundamentally suspicious of all technique.

Richter graduated from the Dresden Art Academy in 1956. The academy's principal mission was to prepare artist-workers for state service, such as painting murals for public buildings and designing political posters. Richter did both of these but he was certain that his life and artistic career lay in the West. In 1959, when travel from East Germany to West Germany was still permissible, Richter had visited Documenta II. ${ }^{23}$ There he saw the work of Jackson Pollock and Lucio Fontana. Richter was particularly impressed by Pollock and saw in his work an authenticity that was absent in the ideologically directed art of East Germany. Speaking of Pollock and Fontana, Richter told Benjamin H.D. Buchloh "I might almost say that those paintings were the real reason why I left the GDR. I realized that there was something wrong with my whole way of thinking." ${ }^{24}$ In 1961, Richter and his first wife, Marianne Eufinger, escaped to West Germany. ${ }^{25}$

This period of Richter's life, education, and artistic beginnings is characterized by a personal resistance to the imposition of ideology. It instilled in him a skepticism of creative authorship and authoritative voices. This cultivated a commitment to a process that eschews both ideology and technique. Richter described this practice as "letting a thing come, rather than creating it—no assertions, constructions, formulations, inventions, ideology -in order to gain access to all that is genuine, richer, more alive: to what is beyond my understanding." ${ }^{26}$ While his strategies in his art have evolved, his work has been persistently guided by a profound skepticism that can be traced to his youth.

\section{God}

The aversion to all ideology that Richter's life under the totalizing systems of Nazism and Communism instilled in him also manifested itself in a skepticism of institutional religion and a disbelief in the existence of God. In a 1993 interview, Richter said, "By the age of sixteen or seventeen I

\footnotetext{
Documenta II was held 11 July and 1 October 1959, in Kassel, Germany.

"Interview with Benjamin H.D. Buchloh, 1986" in (Richter et al. 2009, p. 163).

Richter has been married three times. He married Marianne Eufinger in 1957; they had a daughter and were divorced in 1982. In the same year, Richter married the sculptor Isa Genzken; they were divorced in 1994. Richter married Sabine Moritz in 1995 and they have three children.

26 "Notes, 1985" in (Richter et al. 2009, p. 140).
} 
was absolutely clear that there is no God-an alarming discovery to me, after my Christian upbringing. By that time, my fundamental aversion to all beliefs and ideologies was fully developed."27

By his "Christian upbringing" Gerhard Richter was referencing his father's faith. Horst Richter was a fervent Protestant. When Richter referred to his "Christian upbringing," he was speaking only of his father. His mother, Hildegard Schönfelder, did not share her husband's devoutness. She regarded her husband as intellectually and culturally inferior.

However, Horst was a poor role model. As a teacher, he was required to join the Nazi party. Then he was drafted into Hitler's military. Horst was captured and spent the rest of the war in an American prisoner-of-war camp. Although Horst had no enthusiasm for politics or war, they defined his life. He returned home unable to resume his role as a teacher, husband, or father. The accumulation of these failures became cause for Mother to ridicule Horst and his piety. As Richter's youth imbued in him a distrust of ideology, authority, and father figures, these doubts coalesced in his doubts about God.

Richter's disbelief in God may have also been related to his suspicion of his own creative authorship (although it is not possible to say which of these is impetus for the other). However, just as his doubts about creative authorship have not kept him from the studio, his doubts about God did not keep him from having his children baptized in the church.

Richter's three youngest children, Moritz (born 1995), Ella Maria (born 1996), and Theodor (born 2006), were all baptized in Cologne Cathedral. ${ }^{28}$ Speaking in 2001, Richter said, "I was very moved when our two children were baptized." 29 In 2002, Richter was commissioned to create a window for the south transept of Cologne Cathedral.

The fact that Richter elected to have his three youngest children baptized in a religious ceremony as well as his acceptance of a commission for such a high-profile overtly religious work of art are signs of a potential evolution in Richter's stance towards Christianity, and Catholicism in particular.

As a teenager, Richter had confidently concluded that God did not exist. However, in 1998, Richter told an interviewer that, as he was getting older (he was then sixty-six), he was also changing his views on faith. "I am less antagonistic to 'the holy', to the spiritual experience, these days. It is part of us, and we need that quality." 30

In a 2004 interview, Richter said, "I sympathize with the Catholic Church. I can't believe in God, but I think the Catholic Church is marvelous." And he added, "When we had our two children christened here in the cathedral, my attitude towards the church had already radically changed, and I had slowly begun to realize what the church can offer, how much meaning it can convey, how much help, comfort and security." 31

While the list of 20th century and contemporary visual artists who regard their art as having a spiritual dimension but have eschewed institutional religion is too long to count, Richter is a perhaps unusual case of an artist who embraces institutional religion while remaining skeptical of spirituality.

\section{Cathedral Window}

In 2002, Richter was commissioned to create a window for the south transept of Cologne Cathedral. ${ }^{32}$ Completed three years before Richter began his Strip Painting series, Cathedral Window is an important precedent for the process of design, chance, repetition, and mirroring that Richter employed in Strip.

27 “Interview with Hans Ulrich Obrist, 1993" in (Richter et al. 2009, p. 288).

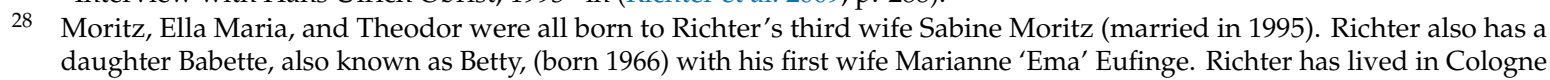
since 1983.

29 (Storr 2003, p. 141).

30 "Interview with Mark Rosenthal" in (Richter et al. 2009, p. 331).

31 "Interview with Jan Thorn-Prikker, 2004" in (Richter et al. 2009, p. 471).

32 For a more extensive discussion of the commission, a contextualizing of this work's visual, conceptual, and spiritual aspects within Richter's oeuvre, and the window's contested reception, see (Romaine 2009). 
The original cathedral window had been destroyed in WWII. The opportunity to create work for such a historically significant building and such a publicly prominent site represented an important milestone in the recognition of Richter as one of Germany's leading artists. Furthermore, since, at that time two of his children had been baptized in this cathedral, the commission was also personally significant for Richter.

The commission specified that the window depict six Christian martyrs of the 20th century. While he accepted the commission, Richter found himself unable to fulfill the expected figurative motifs. Then, the solution presented itself, by coincidence. Richter recalled,

Of course I was impressed by this honorable request, but I soon realized that I was absolutely not up to the task. After a few failed attempts to approach the theme, and when I was almost at the point of giving up entirely, an illustration of 4096 Colors landed on the table. I placed the template of the window's frame on it and saw that this was the only possibility. ${ }^{33}$

Richter found the solution for Cathedral Window, by chance, in a work from 1974, 4096 Colors. ${ }^{34}$ Richter described the process of creating 4096 Colors saying, "the hope is that this way a painting will emerge that is more than I could invent." ${ }^{35}$

For Cathedral Window, Richter worked with 72 colors. He used a computer to generate patterns. He then selected some of these chance-created configurations and rejected others. To give the window a sense of symmetry, he mirrored the composition. This is clearly evident in the lancet windows. For example, in the three lancet windows at the left, a design that is based on the randomly allotted sequence of squares begins at the left and proceeds to the center. But the right half of these three lancet windows is a mirror of the first half.

In a sermon delivered in a special installation Mass, on 25 August 2007, cathedral prelate Josef Sauerborn pronounced, "In chance, the unexpected and unforeseen is hidden. Chance becomes a cipher for the mysterious that transcends our mental capacity." Sauerborn added, "God is not computable; he cannot be contained in any system." ${ }^{36}$

The window gives color and light a material presence. In notes dated 1964-1965, Richter wrote, "The central problem in my painting is light" ${ }^{37}$ While his window for Cologne Cathedral is a fulfillment of that ambition, this strategy is also evidenced in Strip.

\section{Abstract Painting}

If Cathedral Window is one precedent for the process of artist-guided chance that generated Strip, the visual origin of this unique digital print can be found in Abstract Painting (724-4). Painted in 1990, Abstract Painting is a large $(92 \times 126 \mathrm{~cm})$ and vibrant work.

To create Abstract Painting, Richter employed a tool that he invented himself. In the Richter literature, this tool is most often called a "squeegee." However, if this term evokes the idea of a strip of rubber attached to a stick, that is not at all what Richter uses. These squeegees, of various sizes, are custom-made tools of bendable, but firm, sheets of Perspex with an attached wood handle that runs the full length of squeegee.

Richter employs these squeegees like large palette knives. He is able to pull, scrape, and smear the surface of his painting. The Perspex blade leaves behind a commensurate paint surface, except that there are places where the surface has been torn open to reveal the layers below. The result of the method creates a surface that retains a freshness, as if, even years later, the surface still reads as wet.

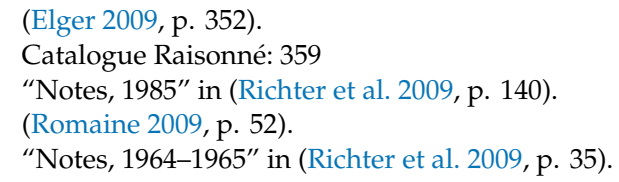


Painters such as Gustave Courbet and J.M.W. Turner, for example, had used the palette knife to smear the paint surface. This method allowed them to highlight the materiality of their paint as surface. However, the small size of the traditional palette knife still left a trace of the artist's hand. Courbet and Turner were exchanging one type of mark, the brushstroke, for a different type of mark made with the knife. Richter uses squeegees that are large enough to cover the entire painting's surface in a single stroke. This eliminates the appearance of the artist's hand.

Richter's squeegee method creates a surface that reads as mechanical rather than handmade. In a 1985 interview with Dorothea Dietrich, Richter acknowledged that these squeegee-created abstractions, despite having a flat, impersonal, surface, still evidence his touch. Richter noted, "I want to avoid at all costs that this personal expression be too direct." ${ }^{\prime 38}$ Speaking of gestural abstraction, Richter added, "Everybody does it and it is very easy. This type of authenticity can be found in many paintings, but in the long run it becomes rather boring. ${ }^{\prime 39}$ He then contrasted gestural abstraction with his own method of artist-guided chance saying, "I like to compare my process of making art to the composition of music. There, all personal expression has been subjugated to the structure ... " 40

The mechanical feel of these abstractions has been consistently interpreted in the Richter literature as his commentary on the state of painting in an age of mechanical, and then digital, reproduction. But Richter's works are more than philosophical musings on the state of painting. Works such as Abstract Painting employ a use of chance, guided by a combination of creative intuition (mind), exacting attention to detail (eye), and precise technical expertise (hand) that Richter has developed over a lifetime in the studio, to present the viewer with a model of looking at, thinking about, and acting in the world. Reading Richter's paintings-visually navigating their surfaces and conceptually excavating their processes of formation - challenges the viewer to see and think in certain directions. They equip us as the viewer to be more critically self-aware of our own precarious state. And yet the unadulterated beauty of Strip and Abstract Painting suggests that all is not lost. We need not abandon hope. The very existence of these works of art offers proof of potential, belief that the inconceivable is possible.

Richter does not regard these so-called "abstract" paintings as nonrepresentational. He said, "Almost all the abstract paintings show scenarios, surroundings or landscapes that don't exist, but they create the impression that they could exist. As though they were photographs of scenarios and regions that had never been seen, that could never exist." 41

Richter's paintings, such as Strip and Abstract Painting, are not abstractions of a representational, i.e., visible or perceptible, world. One can think of Strip and Abstract Painting as exactingly detailed representations (like a painting by Jan van Eyck) of a world that is imperceptible. As representations of "scenarios and regions that had never been seen," it is important to note that Strip and Abstract Painting are entirely nonpictorial. Abstract Painting has material depth, layers created by the squeegee pulling layers of paint over each other, with the underlayers being revealed in the tears of the surface. However, this depth is the result of the painting's material structure, not an illusion of pictorial depth. In pictorial abstraction, such as the works of Kandinsky, the image is nonrepresentational but still retains the characteristics of a pictorial illusion. This method of pictorial illusion, such as it was developed in the Renaissance, was designed to facilitate images, illusions, in which the world depicted more closely corresponded to the world of the viewer. Richter's use of the squeegee entirely eliminates the pictorial. As such, the "scenarios and regions" to which they gain the viewer access is a world that is made materially present by the painting but that is also somehow completely unlike the world of the viewer.

If Richter believes that works such as Abstract Painting are representations of an incomprehensible reality, the Strip Paintings series is, in part, a test of that proposition. The process of creating Strip from Abstract Painting is a journey into the "regions that had never been seen." For Richter, this is a discovery

\footnotetext{
"Interview with Dorothea Dietrich, 1985" in (Richter et al. 2009, p. 145).

"Interview with Dorothea Dietrich, 1985" in (Richter et al. 2009, p. 145).

"Interview with Dorothea Dietrich, 1985" in (Richter et al. 2009, p. 145).

"I Have Nothing to Say and I'm Saying It." in (Godfrey et al. 2016, p. 19).
} 
of worlds within worlds. From one work, Richter could produce, potentially, an infinite number of unique prints. In each print, the strip could be infinitely mirrored to stretch it to any length. Strip is a world beyond representation.

\section{Gaining Access to the Unvisualizable}

The squeegee-created abstract painting represented the most significant development in Richter's art since the beginning of his mature work in 1962. These works differ in both process and concept from his early abstractions. He noted, "What's new about these abstract paintings is the fact that they were not copied from a photograph, nor were they traced from a side-projection of a sketch. Rather, they were freely composed on the canvas." ${ }^{42}$

Being "freely composed on the canvas," the squeegee abstractions introduced the element of chance into his painting process. Previously, Richter had attempted to curtail his authorship through the use of photography. However, these photo-based paintings still evidenced his artistic touch. Richter's blurring of his images had become a sort of signature.

Since the painting created with the squeegee cannot be predicted, Richter relinquishes some control over the painting. But, with practice, the squeegee can be guided. Through the angle of the tool, the pressure applied, as well as the direction and duration of action, he can intervene into the process, as he put it, "giving form to chance, putting it to use." ${ }^{43}$ However, the visual compositions and colors left behind by the squeegee are unplanned as are the rips in the painting's material surface, which allows previously buried layers of paint to become unexpectedly visible.

Richter noted, to himself, "When I paint an abstract picture (the problem is very much the same in other cases), I neither know in advance what it is meant to look like nor, during the painting process, what I am aiming at and what to do about getting there." 44

Richter's biographer Dietmar Elger wrote,

For Richter, the squeegee is the most important implement for integrating coincidence into his art. ... the structure of paint applied with a squeegee can never be completely controlled .... Use of the squeegee thus places him in a situation where he does not have to actively create, but can observe as a paint structure comes into being on the canvas. ${ }^{45}$

Richter activates the material, which has a life of its own; then he decides when to stop and what to keep. In Richter's process, chance is situated between preparedness (such as either the development of a system, as in Strip, or the development of skill, as in the use of the squeegee in Abstract Painting) and judgement.

Richter first used a squeegee in 1980 with an oil-on-canvas painting simply entitled Abstract Painting. ${ }^{46}$ However, this device did not immediately become the principal method of his abstract painting that it has become. Richter has spent years developing and perfecting this method designed to limit his own authorial control. Richter's oeuvre between 1980 and 1982 shows him experimenting with this method and testing the results. Many of these works lack the rich layering of material, form, and color that would come to exemplify Richter's subsequent abstracts.

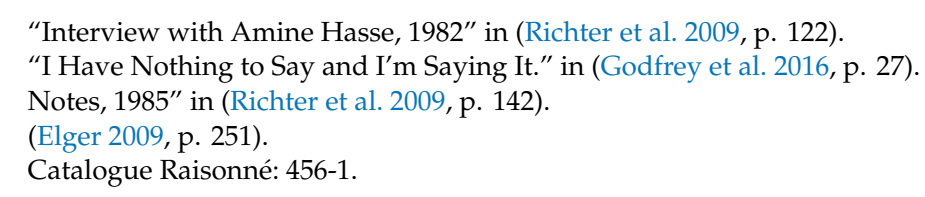


Richter's growing proficiency with this new tool is evidenced in works from 1982, such as Oldenburg, ${ }^{47}$ Yellow-Green, ${ }^{48}$ Red, ${ }^{49}$ Lilac $^{50}$ Orangery, ${ }^{51}$ paintings that he exhibited at Documenta $7{ }^{52}$ Richter's statement for the catalog of his participation in Documenta 7 is perhaps the closest he has come to writing a manifesto for his painting.

He began by arguing for the importance of artificial models of reality, with the work of art being one type, perhaps the best type, of model. But without these models, he wrote, "we would know nothing of reality and would be animals." ${ }^{53}$ This reflects Richter's earlier statement, "Picturing things $\ldots$ is what makes us human; art is making sense and giving shape to that sense. It is like the religious search for God. We are well aware that making sense and picturing are artificial, like illusion; but we can never give them up. For belief ... is our most important characteristic." 54

Richter continued his Documenta 7 text writing, "Abstract pictures are fictive models, because they make visible a reality that we can neither see or describe, but whose existence we postulate." ${ }^{55}$ Therefore, abstract painting not only creates a model of reality but of a reality beyond comprehension. And since this reality is beyond our natural comprehension, we struggle to attach words to it. "We denote this reality in negative terms: the unknown, the incomprehensible, the infinite. And for thousands of years we have been depicting it through surrogate images such as heaven and hell, gods and devils."

Richter continued,

In abstract painting we have found a better way of gaining access to the unvisualizable, the incomprehensible; because abstract painting deploys the utmost visual immediacy ... in order to depict 'nothing' ... . Instead we accept that we are seeing the unvisualizable: that which has never been seen before and is not visible..$^{57}$

Richter concluded his Documenta 7 catalog statement with the bold pronouncement, "Art is the highest form of hope." 58

If Richter's hope is in an art that gains him, and the viewer, access to an incomprehensible and unvisualizable reality, the means to realize this art must also be beyond comprehension. The incomprehensible cannot, after all, be accessed through comprehensible means. In fact, while Richter's oeuvre has not been one of linear progression, there has been an arch of greater complexity. Initially, Richter used found photographs to limit his creative authorship, then he invented a tool that would allow him to more effectively incorporate chance into his process, and, most recently, he has used the computer to make creative choices, which he can accept or reject. Therefore, Strip and the Strip Paintings series are not entry of a painter into the realm of digital printmaking as much as a painting discovering how digital technology can function as a tool in his ongoing contest with his own creative impulse.

\section{Chance}

From Abstract Painting, to Cathedral Window, to Strip, Richter has employed artist-guided chance as a technique of visualizing the incomprehensible. In a 1990 interview, he explained his aim and strategy,

\footnotetext{
47 Catalogue Raisonné: 489.

8 Catalogue Raisonné: 492.

Catalogue Raisonné: 493.

Catalogue Raisonné: 494.

Catalogue Raisonné: 495

Documenta 7 was held 19 June and 28 October 1982, in Kassel, Germany.

"Text for catalog of Documenta 7, Kassel, 1982" in (Richter et al. 2009, p. 121).

"Notes, 1962" in (Richter et al. 2009, p. 14).

"Text for catalog of documenta 7, Kassel, 1982" in (Richter et al. 2009, p. 121).

"Text for catalog of documenta 7, Kassel, 1982" in (Richter et al. 2009, p. 121)

"Text for catalog of documenta 7, Kassel, 1982" in (Richter et al. 2009, p. 121). Italics added.

"Text for catalog of documenta 7, Kassel, 1982" in (Richter et al. 2009, p. 121).
} 
I want to end up with a picture that I haven't planned. This method of arbitrary choice, chance, inspiration and destruction may produce a specific type of picture, but it never produces a predetermined picture. Each picture has to evolve out of a painterly or visual logic: it has to emerge as if inevitably. ${ }^{59}$

According to Richter, everything in life is coincidence. The existence of the universe in its present state is a coincidence. That Richter became a painter is coincidence. That Richter became a famous painter is coincidence. Nevertheless, human beings have creative compulsion, a desire to make something meaningful out of that accumulation of coincidences.

However, for Richter, chance is not meaningless absurdity; it is not automatism. To the contrary, structured chance is creative. In 1986, Richter said, “Above all, it's never blind chance: it's a chance that is always planned, but also always surprising. And I need it in order to carry on ... to introduce something different and disruptive. I'm often astonished to find how much better chance is than I am." ${ }^{\prime \prime 0}$

Richter noted that chance, guided by the artist's decisions, could be creative,

By accepting coincidence as an event that goes far beyond my faculties of imagination, even beyond all comprehension, I take on the role of someone who can only react to it-and yet, despite the helplessness of this position, can still make something out of it, to the point where it is no longer a coincidence any more. ${ }^{61}$

For Richter, chance is the revelation of nature's intellect, which is superior to human intellect or personal choice. Chance is a natural process. That is, nature works by and through chance. In nature, a seed becomes a tree, trees form a forest, by a process that is incalculable and cannot be predetermined. Created by a process that was thoroughly methodical, based on a series of premeditated steps, but that also involved an important element of guided chance, Strip demonstrates how rule-based chance can manifest an orderly design that is greater than the artist's own imagination.

\section{Authorship Revisited}

The process by which Richter created Strip, his use of photography, a computer, and artist-directed chance, all evidence his fundamental suspicion of artistic authorship.

The question of authorship and the authoritative voice of the artist has been one of the central concerns of Richter's art from the very beginning of his oeuvre. ${ }^{62}$ To address his skepticism of authorship, Richter has frequently used conceptual schema to complicate his role as creative author. This can range from making a painting from a found photograph or a store-found color chart to using a computer to organize some 11,500 squares of colored glass for a window in Cologne Cathedral. And yet Richter's authorship continues to be present in the choices he makes, such as his selection of and, contrary to his statements, editing of the photographic image, his decision on when to begin and end the creative process.

Richter's skepticism of authorship, artistic authority, and originality, should, in part, be understood in the context of the climate of post-war German art. The most internationally famous German artist in the 1960s, when Richter was beginning his mature work, was Joseph Beuys. Beuys' creative production, which was comprised mainly of performances and the relics left over from performances, was premised on a cult of artistic personality that is perhaps unsurpassed in the history of art.

59 “Interview with Sabine Schütz, 1990" in (Richter et al. 2009, p. 256).

60 "Interview with Benjamin H.D. Buchloh" in (Richter et al. 2009, p. 182).

61 Gerhard Richter quoted in "Paints and Layers: Abstract Paintings from 1986 to 2005" by Kerstin Küster in (Westheider and Philipp 2018, p. 173).

62 Richter begins his self-created Catalogue Raisonné with works from 1962, even though he had created works before then. It could be argued that what differentiated these excluded works from those included in his Catalogue Raisonné was their approach to creative authorship. 
To advance this doctrine of creative authenticity, Beuys employed a self-invented myth to mask his own personal history and present himself as a shaman healer. Following in the model of authoritative originally set by Beuys, younger artists, such as Georg Baselitz and Anselm Kiefer, began painting in an "authentically Germanic" method of heavily layered materials and gesturalism. These painters, collectively tagged with the Neo-Expressionist label, cultivated a Romantic conception of the work of art as a spiritual revelation of the artist's inner state of being. ${ }^{63}$ Richter's embrace of impersonal methods, from appropriating deadpan photography to his reliance on chance, set him in a different direction from what was championed at the time, between the 1960s and 1980s, as the mainstream of German painting. ${ }^{64}$ However, this strategy was not reactionary; Richter was deliberately improvising strategies that would complicate the issue of creative authorship.

Richter's suspicion of authorship is also, in part, grounded in his own technical dexterity. He was educated in a program, at the Dresden Art Academy, that emphasized traditional methods of drawing from plaster cast and human models. However, it seems that the more skilled he became, the less Richter trusted artistic talent. Technical skills only made it more possible for him to place himself in his own work.

Having achieved a high level of skill, he wanted methods that would short-circuit the emergence of a "signature style." Richter's refusal to work in any particular style is rooted in his belief that style is an expression of the artist. This idea of an artist having a signature style, something like the artist's handwriting, is bound up, at least in Richter's mind, with the idea of a work of art as the outpouring of the artist's inner being.

Richter's approach to painting is the opposite of an artist such as Wassily Kandinsky, for whose work Richter professes an antipathy. ${ }^{65}$ For Kandinsky, the spiritual reality lay within the artist and the work of art was a means of making that inner reality materially visible. Richter rejects this notion of a spiritual reality within the artist waiting to find expression. For Richter, the artist is in the way of the material's own expression of itself. He said, "Pictures should be made according to a recipe. The act of making should occur without inner involvement, like crushing stones or painting a building." ${ }^{66}$ His use of chance is a strategy of clearing himself away.

In "notes" written to himself in 1990, Richter wrote, "Accept that I can plan nothing." ${ }^{\prime 67} \mathrm{He}$ went on,

Any thoughts on my part about the 'construction' of a picture are false, and if the execution works, this is only because I partially destroy it, or because it works in spite of everything - by not detracting and by not looking the way I planned.

I often find this intolerable and even impossible to accept, because, as a thinking, planning human being, it humiliates me to find that I am so powerless. It casts doubt on my competence and any constructive ability. My only consolation is to tell myself that I did actually make the pictures-even though they are a law unto themselves, even though they treat me any way that they like and somehow just take shape. ${ }^{68}$

In an interview with Robert Storr, Richter claimed to be "clumsy" but he added that he has a good eye for judging bad and good art. For Richter, the capacity to decide, to say Yes or No to a manifestation, is the crux for his creativity. ${ }^{69}$ Richter's solution to the problem of authorship is to

63 See (Cowart 1983).

64 Richter was not alone in his avoidance of Neo-Expressionism. He found artist kinship in Sigmar Polke, Blinky Palermo, and Konrad Lueg (later known by his real name Konrad Fischer).

65 (Storr 2003, p. 182).

66 (van Bruggen 1985, p. 86).

67 “Notes, 1990" in (Richter et al. 2009, p. 247).

68 "Notes, 1990" in (Richter et al. 2009, p. 247).

69 (Storr 2003, p. 161). 
employ artist-directed chance. He uses chance to get beyond himself, to reach something greater than himself, something unknown.

However, Richter's doubts should not be confused with ambivalence. He cares and believes deeply. He acts with a sense of purpose. But this sense of purpose is balanced by a skepticism of the result. He is skeptical if the result will be successful. In fact, the success of the work of art for Richter might be if it can succeed in overcoming the artist's skepticism. Richter's much-celebrated doubt is not an end in and of itself. It is his safeguard against a false sense of success. This is not a doubt in the possibility of success, just the certainty that success will not come easily within the limits of human facility. In notes written to himself, Richter wrote, "Of course I constantly despair at my own incapacity, at the impossibility of ever accomplishing anything, of painting a valid, true picture or even knowing what such a thing ought to look like, But then I always have the hope that, if I persevere, it might one day happen." 70

\section{Painting Like Nature}

Richter has placed his hope in the possibility that a more perfect painting might be created by nature, by the process of painting itself rather than being guided by his hand. Artist-guided chance, either through the squeegee tool or some other process, solved one problem in Richter's art in that it seems to have satisfied his desire for equilibrium between fortuitous accident and creative control. Through rule-structured chance, Richter wants to create a work of art that exceeds what a human can make through intention, expression, or technique. However, this process of working by chance also created a new problem. Richter noted, "Using chance is painting like nature-but which chance event, out of all the countless possibilities." ${ }^{\prime 1}$

If he is working by chance, how does Richter know when his painting is finished? According to Richter, "Consciously, I can't calculate the result. But subconsciously, I can sense it."72

In his 1990 "notes," Richter wrote,

... it's still up to me to determine the point at which they are finished (picture-making consists of a multitude of Yes/No decisions and a Yes decision to end it all). If I look at it that way, the whole thing starts to seem quite natural again—or rather nature-like, [the work of art is] alive $\ldots{ }^{73}$

This reference to nature is significant. It goes to the question, "how does Gerhard Richter know when a painting is 'finished'?" In the documentary Gerhard Richter: Painting, which documents him working in the studio over a period of months, the continually present problem is how to know when a work of art is ready to leave the studio and live in the world.

Richter said, "I believe that art has a kind of rightness, as in music, when we hear whether or not a note is false. And that is why the old classical pictures, which are right in their own terms, are so necessary for me. In addition to that there's nature, which I see also has this rightness." ${ }^{\prime 74}$

There are two terms from Richter's statement that need further explanation, "classical pictures" and "rightness."

In an interview with Robert Storr, Richter said, "True classical art—as distinct from conservative classical or neoclassical style-may be defined as an art that accepts its own conventions but does not simply repeat them formulaically. Rather it uses them to transform itself and extend its range."75

\footnotetext{
70 "Notes, 1985" in (Richter et al. 2009, p. 140).

71 "Notes, 1985" in (Richter et al. 2009, p. 140). In her essay, "Painting like nature': Chance and the Landscape in Gerhard Richter's Overpainted Photographs", Aline Guillermet points out that the translation in Text incorrectly reads: 'Using chance is like painting nature' whereas the German reads: 'Den Zufall nützen ist, wie die Natur abmalen'. (Guillermet 2017, p. 198)

72 (Elger 2009, p. 251)

"Notes, 1990" in (Richter et al. 2009, p. 247).

(van Bruggen 1985, p. 82).

(Storr 2003, p. 182)
} 
Richter continued, "A crucial dimension of such classical art, though, is that it is deeply impersonal. Pollock, when he painted the big allover abstractions of the late 1940s and early 1950s, was for perhaps the first time of his life free of himself as a painter and thoroughly involved with the paint and the space and the process. In that sense, his was a classical art."76

So, by "classical painting" Richter means one of the most controversial artists of the 20th century, the Abstract Expressionist Jackson Pollock. This is an insightful point that needs to be returned to, but first, we need to look at the meaning of Richter's concept of "rightness."

In a 1987 interview with Anna Tilroe, Richter said, "I believe I am looking for rightness. My work has so much to do with reality that I wanted to have a corresponding rightness. That excludes painting in imitation. In nature, everything is always right: the structure is right, the proportions are good, the colors fit the forms. If you imitate that in painting, it becomes false." 77

It is interesting that Richter finds the same "rightness" in both a classical work of art and nature. He is not more specific about what constitutes this "rightness" but, it seems to me, this is the goal of his art. When is a painting done? When it has reached "rightness" or an approximation of "rightness."

But how does a painter reach "rightness"? This brings us back to the work of Pollock and Richter's definition of "classical painting." In a statement entitled "My Painting," Pollock described the process by which he created the allover paintings that Richter admired as "classical." He wrote,

When I am in my painting, I'm not aware of what I'm doing. It is only after a sort of "get acquainted" period that I see what I have been about. I have no fears about making changes, destroying the image, etc. because the painting has a life of its own. I try to let it come through. It is only when I lose contact with the painting that the result is a mess. Otherwise there is pure harmony, an easy give and take, and the painting comes out well. ${ }^{78}$

Pollock's statement shares a conceptual kinship with Richter's own 1990 pronouncement that his art is created through a process that is beyond himself, a process that he can only shape through the acceptance or rejection of each unplanned outcome.

In an interview with Nicholas Serota, Richter described the motivation for his persistence in painting, in a period over fifty years, as "a desire to maintain a certain artistic quality that moves us, that goes beyond what we are, and that is, in that sense timeless." 79

\section{Skepticism as a Form of Belief}

Gerhard Richter's writings, interviews, and, most significantly, his art evidence a fundamental skepticism of all received knowledge, including artistic, philosophical, political, and religious teachings. In notes dated from 1962, which are the earliest notes in his collected writings, Richter writes, "There is no excuse whatever for uncritically accepting what one take over from others." ${ }^{\prime \prime 0}$ However, in the very next paragraph, he states,

Picturing things, taking a view is what makes us human; art is making sense and giving shape to that sense. It is like a religious search for God. We are well aware that making sense and picturing are artificial, like illusion; but we can never give them up. For belief (thinking out and interpreting the present and the future) is our most important characteristic. ${ }^{81}$

These statements of doubt and faith are not incongruous; they inform each other.

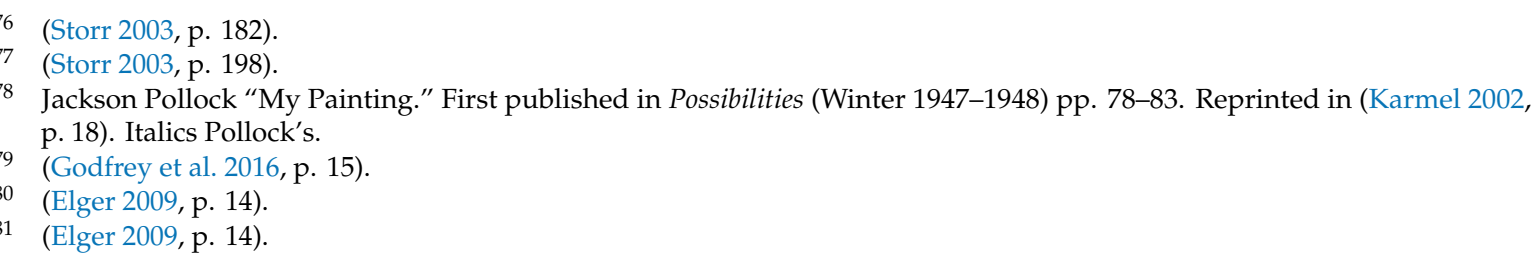


Richter's position echoes that of Marcel Duchamp, whom he greatly admires, when Duchamp, in a filmed interview with James Johnson Sweeney, stated,

I like the word "belief." I think, in general, when people say "I know," they don't know, they believe ... . I believe that art is the form of activity in which man, as man, shows himself to be a true individual and is capable of going beyond the animal state. Because art is an outlet toward regions which are not ruled by time and space.

Then, with a smile, Duchamp concluded, "To live is to believe. That is my belief." 82 Like Duchamp, Richter is skeptical of "knowing" but finds hope in "belief."

Strip is one of the most recent, and arguably one of the most successful, manifestations of a central theme in Gerhard Richter's art, namely the persistent and unfulfilled longing to believe in something larger or greater than himself. His hope of possibly realizing this indefinable purpose prevents this longing from becoming melancholia. Richter's art both visualizes this longing and, by giving material form to this longing, fulfills it, at least in part. And this work of art gives Richter hope that this longing will one day find fulfillment.

In an interview with Benjamin Buchloh, Richter suggested that his art was an expression of longing. To this, Buchloh incredulously asked "Longing for what?" Richter responded "For lost qualities, for a better world - for the opposite of misery and hopelessness." He added, "I might also call it redemption." ${ }^{83}$ Buchloh, who has consistently denied the possibility of the expression of the spiritual in art, changed the subject. However, as an artist, an immensely talented artist, Richter has an awareness of creating something that is more than he imagined. He finds hope, even redemption, in the reality that the work of art can have an indefinable presence that is greater than the sum of its material elements. The work of art has something that the artist didn't put there.

In a paradoxical oeuvre of elusive beauty and agnostic romanticism, Richter's Strip Paintings are among his most conceptually complex and visually intoxicating works. These prints begin from a foundation of skepticism and, through a process of calculated accidents, arrive at a state of material presence that is somewhere beyond belief.

If the work of art models a method of looking at, thinking about, and acting in the world, Richter's Strip encourages the viewer to embrace the inconceivable and to creatively turn the coincidences of life into beauty. Our awareness of ourselves, of our place in the world, and of our as-yet realized potential is expanded by Strip. The digital print makes us more fully human.

In 1989, Richter told an interviewer, "I don't believe in the absolute picture. There can only be approximations, experiments, and beginnings, over and over. ${ }^{\prime 84}$ But in 2002, he told Storr, "A painting can help us to think something that goes beyond this senseless existence. That's something art can do." 85 These statements evidence an optimistic skepticism that is manifested in both the process that created Abstract Painting and then Strip as well as the visual experience of measureless beauty that we find in these works.

The Strip Paintings series represents, in my opinion, the most significant new development in Gerhard Richter's oeuvre since he began using the squeegee three decades ago. If Richter, in turn, is regarded as one of the most important painters working today, then the Strip Paintings series are an important development in the state of contemporary art.

Strip is not likely to be the end of Richter's explorations into the relationship between artist-guided chance and creative authorship. Nor is this series of unique prints likely to be Richter's last endeavor into the realm of the incomprehensible. In 1962, the year that he began his mature work, Richter made notes to himself, saying, "Strange though this may sound, not knowing where one is going — being

\footnotetext{
(Sweeney 1956).

"Interview with Benjamin H.D. Buchloh" in (Richter et al. 2009, p. 181).

"Conversation with Jan-Thorn Prikker concerning the 18 October 1977 cycle, 1989" in (Richter et al. 2009, p. 235).

"MoMA Interview with Robert Storr" in (Richter et al. 2009, p. 431).
} 
lost, being a loser-reveals the greatest possible faith and optimism, as against collective security and collective significance. To believe, one must have lost God; to paint, one must have lost art." 86 Six decades later, Richter's search has gained focus, vigor, and intensity but he finds creative exhilaration in the prospect that it has come no closer to resolution.

Funding: This research received no external funding.

Conflicts of Interest: The author declares no conflict of interest.

\section{References}

Belz, Corinna. 2012. Gerhard Richter Painting. DVD. Berlin: Zero One Film.

Buchloh, Benjamin H. D. 2012. Gerhard Richter: Strip Paintings. New York: Marian Goodman Gallery.

Cowart, Jack. 1983. Expressions: New Art from Germany: Georg Baselitz, Jörg Immendorff, Anselm Kiefer, Markus Lüpertz, A.R. Penck. Munich: Prestel-Verlag in Association with the Saint Louis Art Museum.

Elger, Dietmar. 2009. Gerhard Richter: A Life in Painting. Chicago: University of Chicago Press.

Guillermet, Aline. 2017. 'Painting like nature': Chance and the Landscape in Gerhard Richter's Overpainted Photographs. Art History 40: 178-99. [CrossRef]

Godfrey, Mark, Dorothée Brill, Camille Morineau, Achim Borchardt-Hume, Rachel Haidu, Christine Mehring, and Nicholas Serota. 2016. Gerhard Richter: Panorama: A Retrospective. Expanded ed. London: Tate Publishing.

Karmel, Pepe. 2002. Jackson Pollock: Key Interviews, Articles, and Reviews. New York: The Museum of Modern Art. Storr, Robert. 2003. Gerhard Richter. Doubt and Belief in Painting. New York: The Museum of Modern Art.

Richter, Gerhard, Dietmar Elger, and Hans Ulrich Obrist. 2009. Text: Writings, Interviews and Letters: 1961-2007. London: Thames and Hudson.

Richter, Gerhard. 2012. Gerhard Richter: Patterns: Divided, Mirrored, Repeated. New York: D.A.P./Distributed Art Publishers.

Romaine, James. 2009. Gerhard Richter: The Capacity for Belief. Image 64: 43-56.

Sweeney, James Johnson. 1956. Marcel Duchamp, Interview on Art and Dada. Available online: https: //www.youtube.com/watch?v=DzwADsrOEJk\&t=2s (accessed on 16 April 2019).

van Bruggen, Coosje. 1985. Gerhard Richter: Painting as a Moral Act. Artforum International 9: 82-91.

Westheider, Ortrud, and Michael Philipp, eds. 2018. Gerhard Richter: Abstraction. Munich: Prestel.

(C) 2019 by the author. Licensee MDPI, Basel, Switzerland. This article is an open access article distributed under the terms and conditions of the Creative Commons Attribution (CC BY) license (http://creativecommons.org/licenses/by/4.0/). 